\title{
自己の幹細胞による治療に FDAが「待った」
}

\section{FDA challenges stem-cell clinic}

DAVID CYRANOSKI 2010 年 8 月 19 日号 Vol. 466 (909)

www.nature.com/news/2010/100817/full/466909a.html

患者自身の幹細胞を利用した治療の規制について、米国で訴訟が起こり、 治療を行っている医師たちと安全性を危惧する学術研究機関との論戦も過熱している。

8 月 6 日、米国食品医薬品局（FDA）は、 ワシントン D.C. 連邦地方裁判所に、幹 細胞治療クリニック、リジェネレティブ・ サイエンシーズ社（米国コロラド州ブ ルームフィールド）が行っている治療用 幹細胞の調整の差し止めを求めた。FDA は、幹細胞治療の認可は自分たちの管轄 だと主張している。リジェネレティブ・ サイエンシーズ社（以下、リ社）は、成 人患者の骨髄や滑液から幹細胞を分離し て培養と調整を行い、医師たちが、その 細胞を患者に注射して骨折や腱断裂など の障害を治療する。このクリニックでは、 7000 〜 9000 ドル（約 60 万〜 77 万円） の治療費で、毎月約 20 件の施術を行つ ている。従来の造血幹細胞の骨髄移植と は異なり、同社の施術では、骨や軟骨、 脂肪細胞への分化能力をもつ間葉系幹細 胞が使用されている。

2008 年 7 月、リ社に対して FDA は、 同社の治療が連邦食品医薬品化粧品法で は医薬品、公衆衛生法では生物学的製品 であると通知した。しかしリ社は、FDA に承認を申請することなく治療し続け た。この訴訟で FDA は、リ社が GMP(医 薬品の製造および品質管理に関する規 準) に従っておらず、その治療法の安全 性と有効性が未確認だとしている。

これに対し、リ社の医学担当取締役で ある Christopher Centeno は、この治 療法は患者自身の幹細胞を使うため体外 受精に類する医療行為に当たり、FDA か
らとやかくいわれる筋合いはないと主張 する。また、自身の行う治療に関しては、 従来の手術よりもはるかに高い安全性が 示されており ${ }^{1}$ 、有効性は動物実験と画 像試験 ${ }^{2}$ で確認されていると説明してい る。そしてさらに、臨床試験に基づいて 科学的証拠を示せという FDA の要求は 「もっともな姿勢だが、それが唯一絶対 のものではない」と語つた。Centenoに よれば、医師や患者たち 1100 人からな る「国際細胞医学会 (ICMS ; 米国オレ ゴン州セーレム)」の指針に従えば十分 なのだという。（彼はその設立にかかわ り、医学担当理事も務めている。

Centeno とその支持者は、FDA によ る差し止め命令の請求は、幹細胞治療を 行う病院にとって、幹細胞治療を締め付 け患者自身の細胞の個人的使用を制限し ようとする業界連合という巨大な敵との 戦いでも痛手になる、と口をそろえる。 7 月 30 日付の公開書簡で、ICMS の代 表理事である David Audley は、国際幹 細胞研究学会 (ISSCR ; 米国イリノイ州 ディアフィールド）抽よ゙約 3500 人の 幹細胞研究者たちが、自分たちの病院を 閉鎖させようとしていると非難した。こ の治療法から利益が得られそうにない 製薬業界に動かされた ISSCR が、「すべ ての文明国の法律を変えてこうした治 療法を非合法化しようとしている」と Audley は語る。しかし、Nature からの 質問に対して Audley は、そうした主張

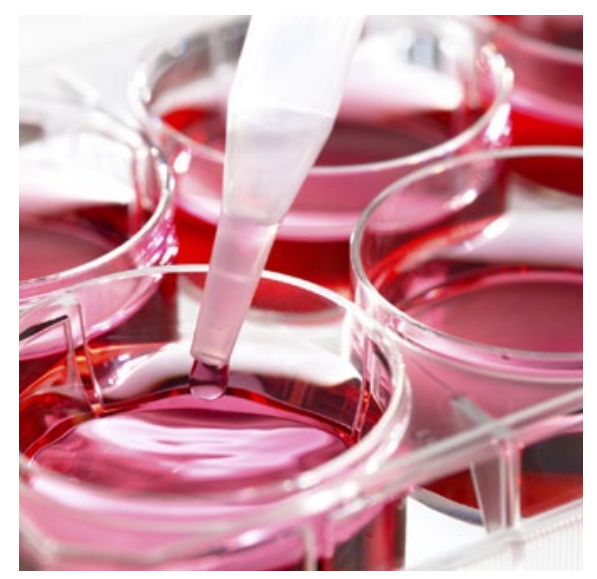

に確固たる証拠があるわけではないこと も認めている。

ロックフェラー大学（米国ニューヨー ク州）に所属する ISSCR 会長の Elaine Fuchs は、Audley らの主張を否定する。 確かに ISSCR は資金の 12 パーセントを 業界から得ているが、目的は基礎科学の 発展であり、業界の利益を支持するため ではないという。

ISSCR は未検証の幹細胞治療を懸念 しているのだ。6月、ISSCR は、治療法 や病院の安全性や有効性を求めに応じ て判定するサービスを開始した。ISSCR の未検証の幹細胞治療に関する委員会の メンバーで、理化学研究所 発生・再生 科学総合研究センター (兵庫県神戸市) に所属する Douglas Sipp は、裁判でリ 社が勝ったら、「深刻な事態に陥るでしょ う」と語る。「企業は、自己由来の医療 製品の安全性と有効性の証明に関する要 求を無視するようになり、『何でもあり』 の風潮が生まれてしまいそうです」。

しかし、Centeno は歴史的勝利を予 感している。「我々が勝てば、培養の有 無にかかわらず、自己由来の細胞の調整 に関する規制の枠組み全体が見直される でしょう。そうなれば、あらゆる医師が、 優れた技術を使い、責任ある態度で、医 療行為の一部として幹細胞を使用するこ とができるようになるのです」。

(翻訳 : 小林盛方)

1. C. J. Centeno et al. Curr. Stem Cell Res. Ther. 5, 81-93 (2010). 2. C. J. Centeno et al. Pain Physician 11, 343-353 (2008) 